\title{
ПРОЦЕССУАЛЬНОЕ ПРАВО:
}

\section{ВОПРОСЫ ТЕОРИИ И ПРАВОПРИМЕНЕНИЯ}

DOI: https://doi.org/10.15688/lc.jvolsu.2017.3.17

UDC 343.1

LBC 67

\section{SOME PROBLEMS OF RECOGNIZING A PERSON AS VICTIM IN A CRIMINAL CASE}

\author{
Yuliya A. Kuzovenkova \\ Academician S.P. Korolev Samara National Research University, Samara, Russian Federation

\section{Yana V. Samiulina} \\ Samara Law Institute of the Federal Penitentiary Service of Russia, Samara, Russian Federation
}

\begin{abstract}
Introduction: the article is devoted to some issues of recognizing a natural and legal person as victim in the Russian Criminal Procedure. The relevance of the issue under study is caused by the lack of a unified approach to the issue of recognizing a person as victim in the case when the inchoate crime caused no actual harm to the person; in this connection, the authors set the goal to study the above-noted issues. To achieve this goal there were used the methods of scientific cognition: comparative law, systemic, analysis and synthesis. The results obtained: by analyzing the scientists' points of view mentioned in the article, the authors noted that the factual grounds for recognizing a person as victim need to be not only the fact of actual harm, but the situation which directly threatens the violation of the person's rights and legitimate interests. Conclusions: the victim is an interested party as to the results of the investigation, conviction and just punishment of the offender. And the international legal acts, the Constitution and the Criminal Procedure Code of the Russian Federation ensure the protection of his rights and legitimate interests. Therefore, we believe it is appropriate to make adjustments to the legal definition of victim given in Article 42 of the Criminal Procedure Code of the Russian Federation, indicating the recognition of natural and legal persons as victims in the event of causing harm to them by "the event of crime".
\end{abstract}

Key words: victim, person, natural person, legal person, criminal procedure, crime.

ПРИЗНАНИЕ ЛИЦА ПОТЕРПЕВШИМ ПО УГОЛОВНОМУ ДЕЛУ

\author{
Юлия Алексеевна Кузовенкова \\ Самарский национальный исследовательский университет им. академика С.П. Королева, \\ г. Самара, Российская Федерация \\ Яна Валерьевна Самиулина \\ Самарский юридический институт ФСИН России, г. Самара, Российская Федерация
}

Введение: представленная статья посвящена отдельным проблемам признания физического и юридического лица потерпевшим в российском уголовном судопроизводстве. Актуальность рассматриваемой 
проблемы обусловливается отсутствием единого подхода по вопросу признания лица потерпевшим в случае, когда лицу неоконченным преступлением не причинен реальный вред, в связи с чем авторами поставлена цель исследования указанного вопроса. Для достижения поставленной цели были использованы методы научного познания: сравнительно-правовой, системный, анализ и синтез. Получены результаты: анализируя приведенные в статье точки зрения ученых, авторами отмечено, что фактическим основанием для признания лица потерпевшим должен быть не только факт реального причинения вреда, но и ситуация, когда права и законные интересы лица непосредственно поставлены под угрозу нарушения. Выводы: как жертва преступления, потерпевший является заинтересованным лицом в отношении результатов расследования, изобличении и справедливом наказании преступника, а международно-правовые акты, Конституция РФ и УПК РФ обеспечивают охрану его прав и законных интересов. В связи с этим полагаем целесообразным внести корректировку легального определения потерпевшего, данного в ст. 42 УПК РФ, с указанием признания потерпевшим физических и юридических лиц в случае причинения им вреда «событием преступления».

Ключевые слова: потерпевший, физическое лицо, юридическое лицо, уголовный процесс, преступление.

\section{Введение}

Согласно ч. 1 ст. 42 УПК РФ потерпевшим является физическое лицо, которому преступлением причинен физический, имущественный, моральный вред, а также юридическое лицо в случае причинения преступлением вреда его имуществу и деловой репутации.

При этом в соответствии со ст. 17 ГК РФ под физическим лицом следует понимать граждан РФ, иностранных граждан, а также лиц без гражданства.

В ст. 48 ГК РФ указано, что юридическим лицом является организация, которая имеет обособленное имущество и отвечает им по своим обязательствам, может от своего имени приобретать и осуществлять гражданские права и нести гражданские обязанности, быть истцом и ответчиком в суде.

\section{Основания признания лица потерпевшим}

Для того чтобы лицо вступило в уголовно-процессуальные отношения в качестве потерпевшего, необходимо формально-юридическое и фактическое основание. Так, исходя из буквального толкования норм уголовно-процессуального законодательства, фактическим основанием признания лица потерпевшим является обязательное причинение ему физического, имущественного, морального вреда, а в случае признания потерпевшим юридического лица - причинение вреда его имуществу и деловой репутации.

Однако в теории уголовного процесса дискуссионным остается вопрос, связанный с возможностью признания лица потерпевшим в случае совершения против него неоконченного преступления.

Понятие неоконченного преступления является законодательным и определено в главе 6 УК РФ. Уголовный закон под неоконченным преступлением понимает не только приготовление и покушение на совершение преступления, но и добровольный отказ от доведения преступления до конца, то есть учитывается любая незавершенность преступления как в силу обстоятельств, от воли лица не зависящих, так и по личному волеизъявлению (добровольный отказ).

Учитывая положение ч. 2. ст. 30 УК РФ, согласно которому уголовная ответственность наступает за приготовление только к тяжкому и особо тяжкому преступлениям, проблему признания лица потерпевшим, на наш взгляд, необходимо поднимать лишь относительно приготовления к вышеупомянутым категориям преступления.

Что касается признания лица потерпевшим в случае оконченного покушения, когда лицо выполнило все необходимое для совершения преступления и причинения вреда, но по не зависящим от него обстоятельствам преступное последствие не наступило, то в теории уголовного процесса данный вопрос решается положительно.

В настоящее время в соответствии с п. 2 Постановления Пленума Верховного Суда РФ от 29 июня 2010 г. № 17 «О практике применения судами норм, регламентирующих участие потерпевшего в уголовном судопроизводстве», судебная практика исходит из того, что если совершенное преступление, являясь неоконченным (приготовление к тяжкому или особо тяжкому преступлению или покушение на 
преступление), причинило лицу реальный, в том числе моральный, вред, то лицо должно быть признано потерпевшим [2]. Данная позиция не противоречит ч. 1 ст. 42 УПК РФ, так как лицу причиняется вред хоть и не оконченным, но все же преступлением. Г.О. Сафарян по этому поводу отмечает, что «причинение вреда и признание за лицом, которому этот вред причинен, определенных процессуальных прав, выступают как причина и следствие» [5, с. 81$]$.

Вместе с тем основная дискуссия в теории уголовного процесса связана с возможностью признания лица потерпевшим в случае, когда лицу неоконченным преступлением не причинен реальный вред.

\section{Признание лица потерпевшим при неоконченном преступлении}

Некоторые авторы, такие как В.М. Савицкий и И.И. Потеружа, утверждают, что если неоконченное преступление не причинило лицу реального вреда, то и нет оснований для признания такого лица потерпевшим [4, с. 8-9]. Здесь стоит отметить, что их исследование об обеспечении прав потерпевшего было одним из первых и проводилось в абсолютно другой нормативно-правовой реальности. На наш взгляд, данная точка зрения ошибочна, так как потерпевший участвует в уголовном процессе с целью защиты своих прав и законных интересов, доказывая при этом, что преступлением ему был причинен тот или иной вред, а нераскрытое приготовление или покушение в дальнейшем может быть повторено, и на этот раз удачно. Поэтому лицо, в отношении которого готовилось преступление, несомненно, заинтересовано в изобличении и наказании виновного лица, а для защиты своих прав и законных интересов оно должно обладать статусом потерпевшего.

Д.В. Шаров предлагает вопрос «о реальном признании потерпевшим при неоконченном преступлении поставить в зависимость от волеизъявления самого лица, подвергшегося посягательству» [6]. Автор считает, что признавать лицо потерпевшим следует только при его желании быть признанным потерпевшим, а если не желает, то не может быть принуждено к этому.
Вместе с тем существует и другая точка зрения, сторонниками которой являются В.И. Рохлин, В.Г. Казанцев и другие. Исследователи утверждают, что при приготовлении или покушении на совершение преступления независимо от причиненного лицу вреда его во всех случаях следует признавать потерпевшим [3, с. 12]. Мы полностью согласны с данной точкой зрения и считаем, что фактическим основанием для признания лица потерпевшим должен быть не только факт реального причинения вреда, но и ситуация, когда права и законные интересы лица непосредственно поставлены под угрозу нарушения.

Формально-юридическим основанием вступления потерпевшего в уголовно-процессуальные отношения является факт принятия решения о признании данного лица потерпевшим. Согласно ч. 1 ст. 42 УПК РФ такое решение принимается незамедлительно с момента возбуждения уголовного дела и оформляется постановлением дознавателя, следователя, судьи или определением суда. Если на момент возбуждения уголовного дела отсутствуют сведения о лице, которому преступлением причинен вред, решение о признании лица потерпевшим принимается незамедлительно после получения данных об этом лице.

Некоторые авторы, например А.В. Гриненко, критикуют настоящее положение уголовно-процессуального закона, говоря о недопустимости наделения должностных лиц, которые ведут производство по уголовному делу, правом принятия решения о признании лица потерпевшим [1, с. 51]. С этой точки зрения можно говорить о сближении уголовно-правового и уголовно-процессуального момента возникновения потерпевшего в уголовном судопроизводстве и установлении общего положения, согласно которому лицо становится потерпевшим непосредственно в момент совершения преступления, независимо от признания его таковым со стороны государства.

Необходимо отметить то, что в уголовном процессе потерпевший занимает особое место. Так, с одной стороны, потерпевший является жертвой события преступления и в соответствии с главой 6 УПК РФ является участником уголовного судопроизводства со стороны обвинения, а с другой стороны потерпевший выступает в качестве носителя 
ценной доказательственной информации об обстоятельствах совершения преступления.

\section{Выводы}

Таким образом, как жертва преступления потерпевший является заинтересованным лицом в отношении результатов расследования, изобличении и справедливом наказании преступника, а международно-правовые акты, Конституция РФ и УПК РФ обеспечивают охрану его прав и законных интересов. В связи с этим, полагаем, целесообразно внести корректировку легального определения потерпевшего, данного в ст. 42 УПК РФ, с указанием признания потерпевшим физических и юридических лиц в случае причинения им вреда «событием преступления».

\section{СПИСОК ЛИТЕРАТУРЫ}

1. Гриненко, А. В. Потерпевший должен иметь не меньше процессуальных прав, чем обвиняемый / А. В. Гриненко // Российская юстиция. 2002. - № 9. - C. 51-52.

2. Постановление Пленума Верховного Суда РФ «О практике применения судами норм, регламентирующих участие потерпевшего в уголовном судопроизводстве» от 29 июня 2010 г. № 17 : (ред. от 9 февр. 2012 г.) // Российская газета. - 2010. - 7 июля (№ 147).

3. Рохлин, В. И. Потерпевший в уголовном процессе / В. И. Рохлин, В. Г. Казанцев // Адвокат. 2011. - № 5. - С. 11-15.

4. Савицкий, В. М. Потерпевший в советском уголовном процессе / В. М. Савицкий, И. И. Потеружа. - М. : Госюриздат, 1963. - 169 с.

5. Сафарян, Г. О. О понятии и основаниях признания потерпевшим в уголовном судопроизводстве / Г. О. Сафарян // Экономика, социология и право. - 2016. - № 1. - С. 79-85.
6. Шаров, Д. В. Признание лица потерпевшим при неоконченном преступлении: вчера и сегодня / Д. В. Шаров. - Электрон. текстовые дан. - Режим доступа: http://www.iuaj.net/node/476 (дата обращения: 25.04.2017). - Загл. с экрана.

\section{REFERENCES}

1. Grinenko A.V. Poterpevshiy dolzhen imet ne menshe protsessualnykh prav, chem obvinyaemyy [The Victim Must Have as Many Procedural Rights as the Accused]. Rossiyskaya yustitsiya, 2002, no. 9, pp. 51-52.

2. Postanovlenie Plenuma Verkhovnogo Suda $\mathrm{RF} « \mathrm{O}$ praktike primeneniya sudami norm, reglamentiruyushchikh uchastiye poterpevshego $\mathrm{V}$ ugolovnom sudoproizvodstve» ot 29 iyunya $2010 \mathrm{~g}$. № 17: (red. ot 09.02.2012) [Resolution of the Plenum of the Supreme Court of the Russian Federation "On the Practice of Courts Applying the Rules Governing the Participation of the Victim in Criminal Proceedings" of June 29, 2010, no. 17 (amend. of February 9, 2012)]. Rossiyskaya gazeta, 2010, July 7 (no. 147).

3. Rokhlin V.I, Kazantsev V.G. Poterpevshiy v ugolovnom protsesse [Victim in the Criminal Trial]. Advokat, 2011, no. 5, pp. 11-15.

4. Savitskiy V.M., Poteruzha I.I. Poterpevshiyv sovetskom ugolovnom protsesse [The Victim in the Soviet Criminal Trial]. Moscow, Gosyurizdat Publ., $1963.169 \mathrm{p}$.

5. Safaryan G.O. O ponyatii i osnovaniyakh priznaniya poterpevshim v ugolovnom sudoproizvodstve [On the Concept and Grounds for Recognizing Victims in Criminal Proceedings]. Ekonomika, sotsiologiya i pravo, 2016, no. 1, pp. 79-85.

6. Sharov D.V. Priznanie litsa poterpevshim pri neokonchennom prestuplenii: vchera $i$ segodnya [Recognition of a Person as a Victim of Unfinished Crime: Yesterday and Today]. URL: http://www.iuaj. net/node/476. (accessed April 25, 2017).

\section{Information about the Authors}

Yuliya A. Kuzovenkova, Candidate of Juridical Sciences, Associate Professor, Department of Criminal Procedure and Criminalistics, Academician S.P. Korolev Samara National Research University, Moskovskoe shosse, 34, 443086 Samara, Russian Federation, kuzovenkova@hotmail.com.

Yana V. Samiulina, Candidate of Juridical Sciences, Associate Professor, Department of Criminal Procedure and Criminalistics, Samara Law Institute of the Federal Penitentiary Service of Russia, Rylskaya St., 24v, 443022 Samara, Russian Federation, yanasam-09@mail.ru. 


\section{Информация об авторах}

Юлия Алексеевна Кузовенкова, кандидат юридических наук, доцент кафедры уголовного процесса и криминалистики, Самарский национальный исследовательский университет им. академика С.П. Королева, Московское шоссе, 34, 443086 г. Самара, Российская Федерация, kuzovenkova@hotmail.com.

Яна Валерьевна Самиулина, кандидат юридических наук, доцент кафедры уголовного процесса и криминалистики, Самарский юридический институт ФСИН России, ул. Рыльская, 24в, 443022 г. Самара, Российская Федерация, yanasam-09@mail.ru. 